\title{
The Politics of Lists
}

Katherine C. Little

University of Colorado Boulder

\begin{abstract}
:
Theorists of materiality frequently present lists of objects in which humans and human-made structures appear with natural objects and phenomena. These lists are importantly symptomatic of the theorists' political interests: to de-center humans and to de-hierarchize human and nonhuman relationships. At the same time, as I argue in this essay, their lists also reveal their participation in and helplessness before the political structures they wish to set aside or reform. Lists, whether in materiality theories or elsewhere, are not always transparently utilitarian; instead they are a recognizable rhetorical, even poetic, device and therefore often do ideological work. After examining the list as a device, I turn to Theseus's famous catalogue of "thynges" at the end of Chaucer's Knight's Tale. In grouping humans and the natural world together, this list naturalizes political hierarchy, concealing the human activity, even violence, that is required to maintain it. Read against Chaucer's list, the lists of the materiality theorists are shown to be doing something similar. By insisting on the shared objectness of all objects, they conceal human activity, in this case the human labor by which many objects are produced.
\end{abstract}

Keywords:

Lists, objects, Knight's Tale, Chaucer, materiality, vital materialism, politics

Jane Bennett begins her influential study, Vibrant Matter: A Political Ecology of Things, with a list of items of trash, found on the streets in Baltimore: "[g]love, pollen, rat, cap, stick." 
The items of trash, captured in this list, cause her to see the world entirely differently; she "achieved, for a moment, what Thoreau made his life's goal: to be able, as Thomas Dumm puts it, 'to be surprised by what we see'"(Bennett 2010, 4, 5). Her interest in the "matter" and "things" of the title thus initially and influentially takes a particular form - the list -- as opposed to lengthy descriptions or stories, and she is not alone in using this rhetorical device. Lists of objects are ubiquitous throughout theories of materiality, the term under which I'm organizing Object Oriented Ontology [OOO], Thing Theory, Actor Network Theory, and vital materialism, so much so that Ian Bogost has invented a term to describe them: "the Latour litany" (Bogost 2012, 49-51). Their ubiquity suggests that they are more than an idiosyncratic tic; the lists often perform the underlying political claims made by such theories, the very act of "de-centering the human" by grouping human and non-human, hyper-objects and objects together on what appears to be a level playing field. In a recent collection of essays entitled, The Nonhuman Turn, the editor Richard Grusin articulates this political position explicitly and then supports it with another list: "the nonhuman turn ... is engaged in decentering the human in favor of a turn toward and concern for the nonhuman, understood variously in terms of animals, affectivity, bodies, organic and geophysical systems, materiality or technologies" (Grusin 2015, iv). Similarly, the list of trash in Bennett's study informs, or is closely bound up with, that book's "political project," which is to "advocate the vitality of matter" and thereby correct "human hubris" and "our earth-destroying fantasies of conquest and consumption" (Bennett 2010, viii, ix).

Even as materiality theorists present their lists as politically and representationally transparent (Bennett is not, after all, writing a poem), the list itself remains for the reader a device familiar from other kinds of texts in which its function is more complicatedly rhetorical or 
even poetic. ${ }^{1}$ Indeed, the inherent poetry of the list can sometimes work against transparency, sneaking back in mystification of the very political structures, such as Bennett's "conquest and consumption," that these theorists explicitly reject, as I shall argue in this essay. In this way, the lists of materiality theorists seem to point to the limitations of their approach; they reinforce helplessness in the face of a consumerist status quo, even as they call for a change in our perception of that status quo. My essay will proceed in two parts: I begin by examining the list as both a poetic and ideological device, with particular reference to lists that link humans and the natural world. I then return to lists in the writings of materiality theorists to demonstrate the way in which their lists disguise some human activity even as they call for reform.

\section{Lists as Poetry}

The most obvious function of the list is to group things or events or people, but before attending to the conceptual aspect of grouping (why these things?), I want to touch very briefly on the aural effect of such groups. After all, an important poetic function of lists is to sound good. When Shakespeare's Prospero calls out, "Ye elves of hills, brooks, standing lakes and groves!" (Shakespeare 1997, 5.1.33), the meaning of these places is less immediately apparent than how they sound, rolling "l's", alternating "v's" and "k's," in almost perfect meter. This is an incantation of sorts, a form of seduction. Lists that sound good can prevent apprehension of the singular object and even rob words of some or all of their meaning. Reynolds Price, a writer who taught at Duke University until his death in 2011, revealed that as a child he had read the telephone book out loud, delighting in the sounds of the names.

As a grouping, the list also asserts a relationship between the things and either implicitly or explicitly draws our attention to why those things belong together, the criteria of inclusion and 
exclusion (See e.g. Belknap 2004, 19; Bernau 2016, Foucault 1970). Prospero's list of places in the landscape, quoted above, does not require us to think too hard about why these places are included or what might be missing, and yet we recognize the items as not only natural but pleasantly familiar, even domesticated. In other lists, the criteria are more obscure, and in this way, the apparent lack of relationship between items draws our attention to the ordering principle. For this reason, lists can be self-conscious or self-reflective, asking readers to think about the list as list as much or more than the individual objects on it (Belknap 2004, 15). Michel Foucault begins his book, The Order of Things, with a list drawn from Jorge Luis Borges, from a “'certain Chinese encyclopaedia' in which it is written that 'animals are divided into: (a) belonging to the Emperor, (b) embalmed, (c) tame, (d) sucking pigs, (e) sirens, (f) fabulous, (g) stray dogs, (h) included in the present classification, (i) frenzied, (j) innumerable, (k) drawn with a very fine camelhair brush, (1) et cetera, (m) having just broken the water pitcher, (n) that from a long way off look like flies"' (Foucault 1970, xv). ${ }^{2}$ For Foucault, such a list "shattered ... all the familiar landmarks of my thought - our thought, the thought that bears the stamp of our age and our geography - breaking up all the ordered surfaces and all the planes with which we are accustomed to tame the wild profusion of existing things, and continuing long afterwards to disturb and threaten with collapse our age-old distinction between the Same and the Other" (Foucault 1970, xv). The challenge for Foucault and readers of such strange lists is to reconstruct the "system of thought" governing the list (Foucault 1970, xv).

To take a medieval example, which might evoke a similar sense of disjointedness, the entry for the year 1066 in the Winchester manuscript of the Anglo-Saxon Chronicle gives a list of events: "Here passed away King Edward, and Earl Harold succeeded to the kingdom and held it 40 weeks and one day, and here came William and won England; and here in this year Christ 
Church burned, and here a comet appeared on 18 April" (Swanton 1998, 194, 196). At first glance, the system of thought seems entirely transparent, since the list briefly details what are recognizably important events in chronological order. And yet, there is a problem with the order. Why is the comet last, even though it appeared about six months before the Battle of Hastings, which is described in the list as "here came William"? There is a "system of thought" at work in this list in addition to chronology. One can speculate that this odd order indicates a traumatic response to the Norman Conquest or a desire to heighten the significance of the comet. Whatever we decide, the list is doing more work than merely presenting important events in the order they occurred.

In gesturing toward the "systems of thought" that inform them, lists offer themselves for and sometimes even seem to demand decoding, what is now known as "hermeneutics of suspicion" or "symptomatic reading" (Best and Marcus 2009, 2, 3-6). A list is not "valueneutral" (Bernau 2016, 261). Grouping various things together can have an ideological function, can mystify the relationships between things, or it can generate suspicion, can demystify the relationships in the list. That is, the list might suggest that everything in 1066 happened for a reason, that William's conquest was as inevitable as a comet, or it can suggest that everything was random, because the comet appears out of sequence. Or perhaps both at the same time. There are many lists, poetic and non-poetic, that perform ideological functions, but I'm going to concentrate on a list that groups humans and human activity with things in the natural world, since that is the focus of so many of the lists in materiality theory. My exemplary ideological list is drawn from the famous speech given by Theseus at the end of Geoffrey Chaucer's Knight's Tale. I will dwell on it at some length, because it is a list that can be read as both mystifying and demystifying an extremely hierarchical even tyrannical political status quo. That this is a 
medieval list is part of my point. Generated out of an earlier "system of thought," Chaucer's list offers a position from which to view the lists of the materiality theorists critically.

Before I focus on the passage, a few remarks will help contextualize this list within The Knight's Tale. The tale is a bleak meditation on the capacity of humans to act in very limited circumstances (Miller 2004; Patterson 1991). Indeed, humans are like objects, imprisoned, exchanged, and toyed with by the gods. The Tale ends with a final speech by the ruler, Theseus, in which he asserts the rightness of the status quo, the importance of hierarchy and subjection in the face of the real human suffering caused by these conditions. This speech has been read straight, as the articulation of a "faith in the ultimate order of all things" (Muscatine 1957, 190); as potentially critical, a "questioning of an established code of values" (Pearsall 1985, 116); and as entirely ironic, part of "a struggle between the Tale and its teller" in which Chaucer gives the Knight a "a Tale (like his world) too complex for his rhetorical management" (Patterson 1991, $168,202) .^{3}$ Although the debate over irony remains unresolved, it is to a certain degree irrelevant for my discussion. No one questions that the speech is about order nor that there are inconsistencies within it, whether those are attributed to Chaucer or to the Knight, and these will be the focus of my discussion. The speech combines different portions of Boethius's Consolation of Philosophy, all related to divine order, with portions of Teseo's speech in Giovanni Boccaccio's Teseida delle Nozze di Emilia, mainly having to do with dying. As Derek Pearsall has noted, "Chaucer's grafting operation ... is not successful" (Pearsall 1985, 124). The list is a catalogue of things that die, and it appears when Chaucer shifts from the Boethian frame to Teseo's speech. It is itself characterized by a further disruption, when Chaucer inserts a few additional lines, apparently of his own invention. 
Theseus's speech is, to recall Bennett's phrase, an overtly political project. It asserts order and an established code of value, and it does so by linking the divine and cosmic order to the social structures on earth. Theseus begins his speech with "that faire cheyne of love," with which God created the elements "In certeyn boundes" (Chaucer 1987, 1.2991, 2993; Aers 1986, 29-32). From this perspective, there is an order and rightness to the way things are, even if people can't see that order. The stability of divine order contrasts with everything on earth, all of which is similarly mutable and, therefore, somehow out of our control:

And therfore, of his wise purveiaunce,

He hath so wel biset his ordinaunce

That speces of thynges and progressiouns

Shullen enduren by successiouns, And nat eterne, withouten any lye.

This maystow understonde and seen at ye. (Chaucer 1987, 1.3011-16).

When Theseus describes the self-evidentness of "thynges" and their mutability we're not entirely sure what kind of things he means. Is he referring to the elements? animals? plants? the monarchy? The earthly "thynges" and the order in this Boethian section remain relatively apolitical precisely because they are unspecified.

It is at this point that Chaucer inserts a catalogue of "thynges," drawing our attention to the relationships between them and making Theseus's political project clearer:

"Loo the ook, that hath so long a norisshynge 
From tyme that it first bigynneth to sprynge,

And hath so long a lif, as we may see,

Yet at the laste wasted is the tree.

"Considereth eek how that the harde stoon

Under oure feet, on which we trede and goon,

Yet wasteth it as it lyth by the weye.

The brode ryver somtyme wexeth dreye;

The grete tounes se we wane and wende.

Thanne may ye se that al this thyng hath ende." (Chaucer 1987, 1.3017-26).

The list is taken from Boccaccio's Teseida, where it serves to illustrate a different point altogether - how everything dies. It's worth quoting the passage from Boccaccio to underscore the limited and conventional context in which the things appear:

6. Cosi chome alchuno che mai non visse

nonmori mai chosi sipuo vedere

chalcun non visse mai che non morisse

e ora che noi viviamo quando piaciere

sara diquelli chel mondo circhunscrisse

percio moremo adunchue sostenere

elpiacier delli dii lieti doviamo

poi chadessi resister non possiamo

7. Lechuerccie che anno silungho mutamento 
etanta quanta noi vedemo

anno pur alchun temp finimento

ledure pietrie anchora che noi calchemo

per accidenti vari manchamento

anchor aver aperto losapemo

e ifiumi per anni esser sechati

veggiamo e altri nuovi esserne nati.

[6. "Just as anyone who did not live could never die, we can see that anyone who did not die could never live and we who are now alive will necessarily die when it pleases the one who set the limits of this world. Therefore we must bear up joyfully under the whim of the gods, since we cannot resist it.

7. The oak trees that have such a long subsistence and great life span, as we see, must also come to an end sometime. The hard stone too, that we trample upon have their ending for different reasons, as we clearly know. And the long living rivers, we see dry up and new ones come to life"]. (Boccaccio 2002, 12.6-7, 353, 577).

Teseo's speech in the Teseida makes a fairly obvious point about the similarity of the oak, stone, and rivers. The obviousness of the point is underscored by the proverbial language, the generalizations about dying that the things then illustrate. Here humans are linked with the natural world in a list of things that die, and such a statement seems to be doing very little political work.

Chaucer's version of the list, in contrast, makes an implicit political claim about the naturalness of human social and political activity, grouping "tounes" with rivers and stones. The 
list thus reinforces Theseus's point, that all "things," are imagined under the divine order and therefore all are natural, and must be accepted as such. Even though "tounes" are not in Boccaccio's list, and even though they are obviously not natural and don't die in the same way as do trees and people, readers have found this list entirely persuasive. The editor of The Riverside Chaucer describes "the ruin of great cities" as "conventional" (Chaucer 1987, 841 n. 3025; referring to Cross 1961, 68-69). Interestingly enough, the long discussion of the mutability of the elements in Ovid's Metamorphoses, a text with which Chaucer was certainly familiar, mentions towns and cities, but only in relation to bodies of water. In Ovid's poem, it is the rivers and seas, on which the towns are located, that matter, and not changes in the towns themselves (Ovid 2000, 15. lines 259-306).

Whether or not Chaucer's list is conventional, it does make use of a familiar form of ideological mystification. Describing social structures as natural tends to stop people from questioning why they are the way they are (Aers 1986, 30-31). This naturalization is quite common throughout writings of the earlier periods, and it has been famously discussed by many critics, including William Empson. Empson's Some Versions of Pastoral explains how this process works, using a quotation from Thomas Gray's "Elegy Written in a Country Churchyard," which also offers a catalogue of natural items:

Full many a gem of purest ray serene, The dark unfathomed caves of ocean bear: Full many a flower is born to blush unseen, And waste its sweetness on the desert air. (lines 53-56 quoted in Empson 1974, 4). 
Empson then goes on to argue, "[b]y comparing the social arrangement to Nature he [Gray] makes it seem inevitable, which it was not, and gives it a dignity which was undeserved" (Empson 1974, 4). One can say the same of Chaucer's poem, which imagines the death of a tree and of a town as parallel and therefore inevitable. And yet, Chaucer's poem is more disturbing than Gray's because his point is not the shared dignity of these various objects, both natural and unnatural, but their shared status as things that are all acted upon. "Enduring" is the word he uses, because they are helpless in the face of some outside force, and it is this helplessness that they must accept, not, as in Gray, their lower social status or thwarted dreams.

Even as Chaucer's version of the list asserts the likeness of towns and rivers, it also asks us to question it, in that self-consciousness, or potential de-mystification, endemic to lists. In setting a "we" in relation to the various objects, Chaucer, consciously or not encourages readers to see the differences between them. "We" are looking at an oak, which "is wasted" (the passive voice). The tree is thus twice an object, of our gaze and of some force that wastes it. Similarly, we are looking at the stone as well as treading on it. Even though it "wastes" as opposed to is wasted, it seems to do so because we are walking on it. When we get to the towns, though, we are watching them grow and diminish, but this kind of watching raises a series of questions. Are we also in the towns? Are we making them change, as we are with the rocks? And if so, can we say that that they are "ending" in quite the same way as a tree or river?

The tensions inherent in the list, between naturalizing social order and de-familiarizing it, emerge more forcefully later in Theseus's speech, when he turns to a discussion of death. Theseus states that everyone must die, no matter his "degree" and that it is wrong to "rebel" against that decree: 
"Of man and womman seen we wel also That nedes, in oon of thise termes two This is to seyn, in youthe or elles age He moot be deed, the kyng as shal a page;

Som in his bed, som in the depe see,

Som in the large feeld, as men may see;

Ther helpeth noght; al goth that ilke weye.

Thanne may I seyn that al this thyng moot deye.

"What maketh this but Juppiter, the kyng,

That is prince and cause of alle thyng,

Convertynge al unto his propre welle

From which it is dirryved, sooth to telle?

And heer-agayns no creature on lyve,

Of no degree, availleth for to stryve.

"Thanne is it wysdom, as it thynketh me,

To maken vertu of necessitee,

And take it weel that we may nat eschue,

And namely that to us alle is due.

And whoso gruccheth ought, he dooth folye,

And rebel is to hym that al may gye." (Chaucer 1987, 1. 3027-46). 
Once again, a comparison with the Teseida demonstrates how Chaucer has altered his source to draw our attention to social structure. Boccaccio's Teseo keeps his focus on the inevitability of death and is entirely uninterested in evoking any political or social associations around it:

8. Degliuomini nonchale dire chassai

emanifesto achuello che lanatura

litira ea tirati sempre mai

de duo termini alluno oaddo schuro

vechiezza piena didistini ghuai

equesta poi da morte piu sicura

e terminate honvero admorte essendo

giovane anchora e piu lieti vivendo

9. Eccierto icredo che allora migliore

lamorte sia quando diviver giova

almodo edove luomo che a valore

non de churare che dovunchue esitrova

fama liserba ilsuo debito honore

elchorpo che rimane nulla altro prova

fa innun luogo che innunaltro morto

ne lalma ne piu pena omen diporto

10. Delmodo dicho anchora ilsomigliante

che chome che alchuno annieghi inmare

alchun simuoia inssul suo letto stante 
alchun per lo suo sanghue riverssare

nele battaglie oinqual vuoi odiquante

maniere puo morire pur arrivare

ad creonthe ciascheduno conviene

muoia chome sivuole homale hobene

11. E poi fare dela neciessitate

virtu quando bisognia essapianzza

elchontrario echiara vanitate

eppiu inchuello che na ispirienzza

chonchuello che mai nolla anchor provate

[8. "Needless to say, it is very clear that nature pulls, and has always pulled men to one of two ends: either toward an obscure old age filled with endless woes to which death most certainly puts an end, or toward death when still young and most joyfully alive.

9. And I certainly believe then that death is better when living is a joy. The noble man should not be concerned about its manner and its time, for, wherever he may be, fame will secure his deserved honors. And the body that remains will be well in a place or in another, once it is dead, and the soul does not derive more pain or less pleasure from it.

10. I say the same for the manner because, whether a person drowns in the sea or dies in his own bed, or sheds his blood in battle or in whatever way you conceive one may die, yet everyone will have to go to Acheron, however one may die either well or badly. 
11. And, when proper, it is wise to make a virtue of necessity and doing the contrary is clearly futile and more so for a man who had experience of it than for the one who had never tried it"].

(Boccaccio 2002, 12.8-11, 354, 577-78).

After emphasizing at some length the various ways that men can die, Teseo moves immediately to the advice: "E poi fare dela neciessitate/ virtu" or make the best of the circumstances beyond your control. The assumption throughout seems to be that "luomo che a valore [the noble man]" is making a choice about dying, and the discussion doesn't consider other kinds of men who die or the nature of nobility itself. Chaucer's Theseus, despite the fact that he is also, presumably addressing the "noble men" of the parliament with his speech, introduces social structure into a discussion of what Boccaccio insists is merely natural. Theseus states that all people die regardless of their social standing, "the kyng as shal a page" (3030), and "no creature on lyve/ Of no degree" (3039-40). He also moves the observation "we cannot resist it [death]" from the opening of the speech to quite far into it, and directly after his references to Jupiter as king and prince. Although Jupiter obviously stands here for God, and although king and prince are terms often used to describe God, there is also a political undercurrent to this terminology that causes us to read "stryve" and "rebel" in political terms. By the end of the speech, the reader understands not only that death is inevitable, as Boccaccio would have it, but that social degree is inevitable as death, and we should not strive against it. At the same time that Chaucer is naturalizing social structure in this speech, he is also undercutting by assigning it to Theseus. Theseus's self-interestedness is hard to miss, and readers tend, therefore, to see this moment as ironic (Aers 1986, 29-30). The speech, with its strange list, can easily be read as symptomatic of 
Chaucer's skepticism about his current political situation or of totalizing philosophical systems (Guidry 2008, 161; Zeeman 2014, 228).

\section{Vitally Material Lists}

Theorists of materiality are not writing poetry, as Chaucer was, or even history, as were the Anglo-Saxon chroniclers, and their lists seem at first to defy the poetic, or rhetorical, listfunctions discussed above. At the same, however, their lists are not purely or exclusively utilitarian, in the way of a grocery list or a recipe or the phone book. Rather, these lists explicitly refuse traditional ordering principles, such as what sounds good (the aural effect) or "systems of thought," in order to create new rhetorical functions for lists: transparency and radical inclusivity. The "Latour litany," to adopt Bogost's term, proudly attempts randomness in an online list generator: http://bogost.com/writing/blog/latour litanizer/. ${ }^{4}$ Such a list claims to be new because it tells us, as most lists do not, how it was generated. In addition, this list has no limits, since it potentially includes everything in existence or at least the vast number of "things" found on the internet.

These new rhetorical functions for lists, transparency and inclusivity, are tied to a new political consciousness. Bogost describes his Latour litanizer in a strange mixture of playful and corrective terms: "Like all Latour Litanies, this little gadget underscores the rich diversity of things. It also reminds us that human beings are among them" (Bogost 2009; my emphasis). Similarly, in Bennett's Vibrant Matter, the list represents the "assemblage" in which humans are connected to non-humans $(2010,37)$. Redefined as an assemblage, the list helps imagine new terms for desired political arrangements. In the introduction to the special issue of postmedieval on Eco-materialism, lists bespeak human "entanglement" with the non-human: "Environmental 
criticism recognizes possibility in worldly enmeshment, calling upon us to work toward change, justice. Yet, this ecological entanglement can itself transform the ways we envision, experience and embody environmentality, especially when we realize the potent agency of the nonhuman" (Cohen and Duckert 2013, 4). Similar list-like terms for describing these new views abound. Some advocate a "non-anthropocentric, universalized correlationism" (Steel 2012, 33); others use "neighboring" (Houlik-Ritchey 2017). Both terms turn a list into a political ideology, or they turn a political ideology into a rhetorical device.

The lists' claim for political transparency is not naïve, in the way that the list of events from the Anglo-Saxon Chronicle might appear to be, but stems from a kind of knowingness about ideology that I'll call "post demystification." That is, materiality theorists approach the list as a tool for setting aside ideologies or even the idea of ideology. Everything, including critical approaches used to demystify lists, can be on the list; everything is connected and should be approached as such. In this way, the lists signal the utopian possibilities to those tired of critique and demystification (Bennett 2010, xiii-xv). The attitude of post-demystification found in the list is typical of theories of materiality more generally. After all, one of the informing ideas behind these theories is that we are trapped by our terminology of critique, which belongs to the fantasy of modernity. From this perspective, the project of de-mystifying, such as showing how social structures are naturalized in the Knight's Tale, as I have done, is to offer a critique that goes nowhere. Critique merely reinscribes a fantasy of human agency "that has illicitly been projected into things" (Bennett 2010m xiv). As Latour writes, "instead of a resource, the critical spirit becomes a topic, one competence among others, the grammar of our indignations" (Latour 1993, $44,5-8)$. 
And yet, the explicit insistence on transparency of the list and its claims to transcend both mystification and demystification are sometimes contradicted by the very rhetorical workings of the list. One cannot deny the theorists' obvious and even poetic "delight" in the words on their lists (Belknap 2004, 20). Despite asserting the transparent reality of the trash, the attention that Bennett devotes to this list in two different volumes lends it an almost symbolic significance that is somewhat at odds for its claims to thingness (Bennett 2010, 4, 5; Bennett 2012, 238-39). The Latour litanizer is supposed to be fun, hopeful that we are surprised at the juxtapositions we see on our screens. As Andrew Cole, in his critique of OOO, rightly notes, there is love in these lists: “[t]alk of 'thingly' consciousness as vitality or voice will not 'indicate' much of anything but a philosopher's love of language, consumer goods, and entertaining thing-examples like hailstones and tar, aardvarks and baseball” (Cole 2013, 115).

The seductiveness of the lists should also suggest the way in which they might be performing ideological work at odds with their explicit claims for de-centering and dehierarchizing. That is, the desire to put all things including humans together is not, from the perspective of Chaucer's or even Thomas Gray's list, so radical, but can perform the familiar ideological task of naturalizing consumer goods, social divisions, and human activities. The Latour litany might insist, as Chaucer does, that towns are the same as rivers, or, as Gray does, that humans are the same as gems. It does so, however, to reinforce this relationship and not to question or challenge it, as Gray or Chaucer might potentially have done. In an essay collection indebted to Bennett's approach, Animal, Vegetable, and Mineral: Ethics and Objects, Jeffrey Jerome Cohen introduces the essays with a list of his own: "the essays collected in this volume make a cogent, collective argument that things matter in a double sense: the study of animals, plants, stones, tracks, stools, and other objects can lead us to important new insights about the 
past and present" (Cohen 2012, 7). The list presents the objects as all the same, but they are importantly not the same. The stool is a product of human labor; the plants and animals may or may not be products; and the stones likely are not. Such a list of things can never be corrective or egalitarian or utopian as long as it fails to address the human labor upon which these things depend for their very status as things (Edwards 2010, 296-97; Rowlands 2005, 80, 85). That is, to put a manufactured thing, such as a blender or the electrical grid, in a list with a thing that is not a product of human labor, such as a comet or a tree, is to conceal the labor that went into making the thing and the power structures that determine the conditions of labor. Such a list occludes precisely that "conquest and consumption" against which the list is supposedly directed. $^{5}$

Even if a list of objects as objects can be as utopian or egalitarian or decentering as these theorists wish, its insistence on objectness can also communicate helplessness in the face of larger forces, the status quo in which we find ourselves. In Chaucer's list, the towns and rivers, the Boethian "thynges" including humans, must all endure; that is what they have in common. Theseus's observations about their thingness are presented not merely as neutral description but as hortatory. That is, he actively encourages his listeners to see themselves as "thynges," bound like the elements, so that they do not "strive" and "rebel" against him. Although vital materialism assigns agency to non-humans (actants) as part of its utopian corrective, such writings also simultaneously underline the lack of agency of humans. Bennett understands her book to be a political project, and yet her proposals for political action are muted. One might contrast the clear assertion of the "call" of things with the hesitation and vagueness of what the individual human should do: "[p]erhaps the ethical responsibility of an individual human now resides in one's response to the assemblages in which one finds oneself participating: Do I attempt to 
extricate myself from assemblages whose trajectory is likely to do harm?" (Bennett 2010, 4, 37). It's relatively easy to translate this statement into the more satisfactory language of activism: I should boycott a product or store because it exploits workers, pollutes the environment, and so on. And yet, the vagueness of "extricate" and "assemblages" seems designed to deflect questions about what exactly is to be done. What if I can't extricate myself? What if my "extrication" occurs only in language, in the terms that I use to describe myself and not in my actual, lived relationship with other objects and other people?

These terms, and the lists that accompany them, are fundamental to the project of the materiality theorists, and that is to change how we see ourselves, whether in the playful "reminding" of Bogost's Latour litanizer or the visionary urgency of Bennett's "bear[ing] witness to the vital materialities that flow through and around us" (Bennett 2010, x). These are certainly admirable goals, but they are as imbricated in a particular political context as Theseus's speech to parliament. To claim that materiality theory is somehow outside that political context might ultimately reinforce the exploitative systems, the "conquest and consumption," that we might desire to change.

\section{ENDNOTES}

I would like to thank the editors of Exemplaria for organizing the symposium out of which this essay emerged, and Liz Scala and the graduate students of the University of Texas, Austin for being such wonderful hosts. I am also grateful to all of the participants and attendees for the stimulating discussions, many of which helped shape this essay.

${ }^{1}$ The list as a device is somewhat under-theorized, likely because it often has a simply utilitarian function. I have benefited from the essays collected in a special issue of the journal Style 50.3 (2016) and from Belknap's The List.

${ }^{2}$ Many thanks to Paul Neimann for drawing my attention to this passage in Foucault. 
${ }^{3}$ There is an immense amount of criticism on the Knight's Tale, and I have referred only selectively to it, using Derek Pearsall's overview in The Canterbury Tales to represent the accepted view of Chaucer's relationship to his sources (Pearsall 1985, 114-38).

${ }^{4}$ Many thanks to Drew Daniel who mentioned this generator to me in the discussion after my paper.

${ }^{5}$ Aden Kumler also notes the problem of labor in theories of materiality (Kumler 2015, 31).

WORKS CITED

Aers, David. 1986. Chaucer. Atlantic Highlands, NJ: Humanities Press International, Inc.

The Anglo-Saxon Chronicle. 1998. Translated and edited by Michael Swanton. New York: Routledge.

Belknap, Robert E. The List: The Uses and Pleasures of Cataloguing. New Haven: Yale University Press, 2004.

Bennett, Jane. 2010. Vibrant Matter: a Political Ecology of Things. Durham: Duke University Press.

Bennett, Jane. 2012. "Powers of the Hoard: Further Notes on Material Agency." In Animal, Vegetable, Mineral: Ethics and Objects, edited by Cohen, 237-69. Washington D.C., Oliphaunt Books.

Bernau, Anke. 2016. “Enlisting Truth.” Style 50 (3), 261-79.

Best, Stephen, and Sharon Marcus, "Surface Reading: An Introduction," Representations 108.1 (2009): 1-21.

Boccaccio, Giovanni. 2002. Theseid of the Nuptials of Emilia (Teseida delle Nozze di Emilia). Translated by Vincento Traversa. New York: Peter Lang.

Bogost, Ian. 2012. Alien Phenomenology or What It's Like to Be a Thing. Minneapolis: University of Minnesota Press.

Bogost. Ian. 2003-17. “Latour Litanizer” http://bogost.com/writing/blog/latour_litanizer/.

Chaucer, Geoffrey. 1987. The Riverside Chaucer. Boston: Houghton Mifflin.

Cohen, Jeffrey Jerome, ed. 2012. Animal, Vegetable, Mineral: Ethics and Objects. Washington, D.C.: Oliphaunt Books.

Cohen, Jeffrey Jerome and Lowell Duckert. 2013. "Howl." postmedieval 4 (1): 1-5. 
Cole, Andrew. 2013. "The Call of Things: A Critique of Object-Oriented Ontologies." the minnesota review 80, 106-18.

Cross, J.E. 1961. "On the Genre of The Wanderer" Neophilologus 45 (1), 63-75.

Edwards, Jason. 2010. "The Materialism of Historical Materialism.” In New Materialisms: Ontology, Agency, and Politics, edited by Diana Coole and Samantha Frost, 281-98. Durham, NC: Duke University Press.

Empson, William. 1974. Some Versions of Pastoral. New York: New Directions.

Foucault, Michel. 1970. The Order of Things: An Archaeology of the Human Sciences. New York: Vintage Books.

Guidry, Marc S. 2008. "The Parliaments of Gods and Men in the Knight's Tale." Chaucer Review 43.2, 140-170.

Houlik-Ritchey, Emily. 2017. "Ecologies of the Neighbor." Paper presented at Exemplaria: The Second Symposium, Austin, TX, March 31-April 1.

Kumler, Aden. 2015. "Manufacturing the Sacred in the Middle Ages: The Eucharist and Other Medieval Works of Ars." English Language Notes 53 (2), 9-44.

Latour, Bruno. 1993. We Have Never Been Modern. Translated by Catherine Porter. Cambridge: Harvard University Press.

Miller, Mark. 2004. Philosophical Chaucer: Love, Sex, and Agency in the Canterbury Tales. Cambridge: Cambridge University Press.

Muscatine, Charles. 1957. Chaucer and the French Tradition: A Study in Style and Meaning. Berkeley: University of California Press.

Ovid. 2000. The Metamorphoses. Translated by A.S. Kline. University of Virginia Library. http://ovid.lib.virginia.edu/trans/Ovhome.htm

Patterson, Lee. 1991. Chaucer and the Subject of History. Madison: University of Wisconsin Press.

Pearsall, Derek. 1985. The Canterbury Tales. London: George Allen \& Unwin.

Rowlands, Michael. 2005. “A Materialist Approach to Materiality.” In Materiality, edited by Daniel Miller, 72-87. Durham: Duke University Press. 
Shakespeare, William. 1997. The Norton Shakespeare: Romance and Poems, edited by Stephen Greenblatt, Jean E. Howard, and Katharine Eisaman Maus. New York: W.W. Norton and Company.

Steel, Karl. 2012. "With the World, or Bound to Face the Sky: The Postures of the Wolf-Child of Hesse." In Animal, Vegetable, Mineral: Ethics and Objects, edited by Cohen, 9-34. Washington, D.C., Oliphaunt Books.

Zeeman, Nicolette. 2014. "Philosophy in Parts: Jean de Meun, Chaucer, and Lydgate." In Uncertain Knowledge: Scepticism, Relativism, and Doubt in the Middle Ages, edited by Dallas G. Denery II, Kantik Ghosh, and Nicolette Zeeman, 213-238. Turnhout, Belgium: Brepols. 